\title{
Evaluation of compost from seaweed and fish waste as a fertilizer for horticultural use
}

\author{
M. Illera-Vives ${ }^{a}, *$, S. Seoane Labandeira ${ }^{b}$, L.M. Brito ${ }^{c}$, A. López-Fabal $^{\text {a }}$, \\ M.E. López-Mosquera ${ }^{a}$ \\ a Instituto de Biodiversidad Agraria y Desarrollo Rural (IBADER), Universidad de Santiago de Compostela, Campus Universitario, 27002 Lugo, Spain

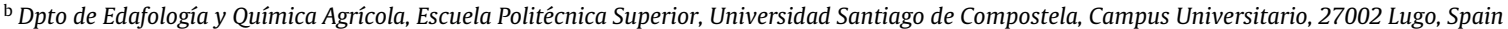 \\ c Montain Research Centre (CIMO), Escola Superior Agrária, Instituto Politécnico de Viana do Castelo, Refóios, 4990-706 Ponte de Lima, Portugal
}

\section{A R T I C L E I N F O}

\section{Article history:}

Received 10 October 2014

Received in revised form 9 January 2015

Accepted 9 February 2015

Available online 5 March 2015

\section{Keywords:}

Organic agriculture

Solanum lycopersicum

Lactuca sativa

Algae

Waste management

\begin{abstract}
A B S T R A C T
Composting may be an effective process for treating fish waste and drift seaweed to recover organic matter and nutrient resources and to produce fertilizers for organic agriculture. The aim of this study was to evaluate the use of this type of compost as a fertilizer in a horticultural crop rotation. A greenhouse trial was carried out to test the effects of the compost on a tomato crop and its residual effects on the succeeding lettuce crop. Different compost rates (C1, C2 and C3: $40 \mathrm{tha}^{-1}, 50 \mathrm{tha}^{-1}$ and $66 \mathrm{tha}^{-1}$ ) were compared to single rates of a mineral fertilizer $(\mathrm{M})$ and of a certified organic fertilizer made from dehydrated broiler litter (BL) as well as to the control treatment, which lacked fertilization (C). Tomato yield increased significantly $\left(5.56 \mathrm{~kg} \mathrm{plant}^{-1}\right)$ with the highest rate of compost compared to the mineral and control treatments ( 4.54 and $4.58 \mathrm{~kg} \mathrm{plant}^{-1}$, respectively). This increased yield was associated with an increase in the diameter and weight of the fruits. Moreover, the lettuce yield improved with compost rates C2 (395 g lettuce $^{-1}$ ) and C3 (367 g lettuce $^{-1}$ ), showing a strong residual effect of the compost. This compost is suitable as organic soil fertilizer and may be recommended for improving horticultural crop yields.
\end{abstract}

(C) 2015 Elsevier B.V. All rights reserved.

\section{Introduction}

The organic matter (OM) content of soil is one of the main indicators of its quality and agronomic productivity, and the influence of OM on the physical, chemical and biological qualities of soil has been widely reported (Reeves, 1997). Organic matter accumulates in soil when carbon (C) inputs exceed C outputs, and in agricultural systems, losses of OM due to mineralization generally exceed gains because of the large amounts of OM removed during crop harvesting. The practice of harvesting most biomass of crops along with other factors, such as intensive soil tilling, accelerates the loss of C from the soil (Weil and Magdoff, 2004). Organic materials have been used for centuries to counteract these losses of soil OM and to supply variable amounts of nutrients to the soil.

Suitable materials for composting are found abundantly in coastal areas. One such material is fish waste, which is yielded as a by-product of fish markets and fish processing industries. Depending on the type of transformation, the waste may represent between 30 and $45 \%$ of the initial weight of the product. The most

\footnotetext{
* Corresponding author. Tel.: +34 982823132.

E-mail address: marta.illera@usc.es (M. Illera-Vives).
}

common destination for these by-products is fishmeal production, in a management system that yields economic benefits for the businesses involved. Fish waste is suitable for agricultural use because it contains large amounts of nutrients, such as $\mathrm{N}, \mathrm{P}$ and $\mathrm{Ca}$ (Illera et al., 2010). Several fertilizers made from fishmeal are now commercially available and some are authorized for use in organic agriculture (EC Regulation 2092/91, 1991). Even fish effluent can be used to irrigate cherry tomato plants (Castro et al., 2006).

Another resource available in coastal areas is beached seaweed that is deposited on beaches in large amounts as a result of tidal or wind action. Drift seaweed is a natural resource in coastal habitats and has been used sustainably in agriculture for several centuries (Zemke-White and Ohno, 1999; McHugh, 2003) due to its value as a fertilizer. Seaweed is particularly rich in potassium (K) and micronutrients as well as growth activators such as auxins, cytokines and alginates, which improve the soil structure (Blunden, 1991; Verkleij, 1992; López-Mosquera and Pazos, 1997; Stirk et al., 2004; Papenfus et al., 2013). In addition, seaweed is a resource with many applications in human life, such as human food, animal feed or in the industry due its high polysaccharide content. Nevertheless, algae sometimes represents a waste, causing eutrophication and generating the so-called green tides (Morand and Briand, 1996) that cause serious environmental problems in different parts of the 
world. These green tides affect coastal activities such as the recreational use of beaches (Rosenberg, 1985; Piriou and Menesguen, 1992; Eyras et al., 1998), aquaculture and shellfish harvesting (Niell et al., 1996). When this occurs, the algae are usually removed and dumped, leading to the loss of a potentially valuable resource.

Both of the above-mentioned materials are of great potential use in agriculture. However, the stabilization of these types of materials is recommended prior to their use to prevent problems associated with the appearance of phytotoxic substances (Michalak and Chojnacka, 2013) and to diminish their water contents and transportation costs. Composting is one of the least expensive methods of stabilizing waste materials. Several studies have evaluated the fertilizer effects of composts and have suggested composting as one of the most appropriate techniques for producing organic fertilizers (Han et al., 2014; Potoky et al., 1988; Piriz et al., 2003). Composting fish waste has also been suggested as a valid method of transforming this waste into useful soil amendments for agricultural purposes (Frederick et al., 1989).

The application of high quality organic amendments to agricultural land has the benefit of being environmentally sustainable and compatible with organic production systems. Organic agriculture is undergoing constant growth worldwide, and at present 1.8 million farmers in 162 countries apply organic agricultural techniques to more than 37 million hectares of land (Willer and Kilcher, 2013). These farms cover the demands of a large market of consumers who are willing to pay relatively high prices for organic products (Govindasamy et al., 1998), reaching a value of 59.100 million US dollars in 2010 (MAGRAMA, 2011).

Tomato is one of the most important crops in Europe, with a production of approximately 16 million tonnes in 2012 of which one third were grown in Spain (EUROSTAT, 2013). However, the effect of organic fertilizers on tomato production is not entirely clear. Some authors have reported higher yields with organic fertilizers compared to mineral fertilizers (Moral et al., 1996; Eyras et al., 1998), whereas other authors either suggested the opposite (Heeb et al., 2005a; Heeb et al., 2005b, 2006) or did not find any significant differences in the tomato yields produced by these two types of fertilizers (Kong et al., 2005). The discrepancy in the findings may be due to the heterogeneity of the physical and chemical characteristics of the different organic fertilizers, which may give rise to different yields even under the same crop conditions. This was shown by comparison of eight types of organic fertilizers (Kanal and Kuldkepp, 1993), which included cattle dung with and without litter, pig slurry, peat compost formed from hen and pig slurry, sawdust-duck manure, non-composted peat and straw litter with pig slurry applied to potato and cereal crops. The findings of that study indicate that the results obtained with different types of organic fertilizers are not readily comparable, and thus a specific agronomic evaluation is required for each type of organic fertilizer, crop and type of management.

The objectives of this research study were as follows: (i) to evaluate fish waste and seaweed compost as a fertilizer for greenhouse-grown tomato; and (ii) to evaluate the residual fertilizing effect of the compost on a lettuce crop grown immediately after harvesting the tomato without any further addition of fertilizer.

\section{Materials and methods}

\subsection{Materials}

The trial was carried out in a greenhouse with acidic soil ( $\mathrm{pH} 4.2)$ developed from quartz schist. The soil had a low effective cation exchange capacity (CECe) $\left(8.2 \mathrm{cmol}(+) \mathrm{kg}^{-1}\right)$, high electrical conductivity (5.6 dS $\mathrm{m}^{-1}$ ) and an appropriate OM content of $3.1 \%$. In spite of the low initial $\mathrm{pH}$ value, it was not amended because the $\mathrm{Al}$ saturation in CECe (which is the main limiting factor in acidic soils) was low enough $(4.7 \%)$ to allow for the proper production of the tested crops.

The compost derived from seaweed and fish waste was produced using the Windrow method with the following feedstock materials: (1) drift seaweed (mainly comprising Laminaria spp. and Cystoseira spp.) collected on the northern coast of Galicia (NW Spain), (2) mackerel (Trachurus trachurus L.) waste from a fish filleting plant, and (3) pine bark $(10-15 \mathrm{~mm})$, which was included as a structural material and as a source of carbon. The final ratio of these materials was 1:1:3(v/v). The thermophilic stage lasted for approximately 45 days, and after the maximum temperature was reached, the pile cooled slowly until it was close to ambient temperature. Water was not added throughout the process. After 10 weeks, the maturity of the compost was established by measuring parameters such as the degree of stability and performing the Dewar flask test and phytotoxicity test. The finished compost had an $\mathrm{OM}$ content of $82 \%$, indicating that this compost may be suitable as an organic soil amendment. The compost contained essential nutrients, with an $\mathrm{N}-\mathrm{P}-\mathrm{K}$ ratio of 2-0.6-0.7 (\% dry weight). Most of the $\mathrm{N}(89 \%)$ was in organic forms. The neutral $\mathrm{pH}$ (6.8) ensured a good availability of the nutrients for the plants and for biological activity. The $\mathrm{C} / \mathrm{N}$ ratio was approximately 22 and the heavy metal content was low. The only limiting feature was the high salinity ( $\left.2.5 \mathrm{dS} \mathrm{m}^{-1} 1: 5\right)$. A detailed description of the composting process and its characterization can be seen in Illera-Vives et al. (2013).

The dehydrated broiler litter, was produced with fresh chicken manure passed through a drying tunnel at $250{ }^{\circ} \mathrm{C}$ before being triturated with a hammer mill, homogenized, and finally pelleted in a granulator press to 5-mm diameter pellets with a length of 12-14 mm. A detailed description of this process and its characterization can be seen in Lopez-Mosquera et al. (2008). The commercial fertilizer had an N-P-K ratio of 3:1.3:2.5 (\% dry weight), with $80 \%$ of the $\mathrm{N}$ in organic forms and a neutral $\mathrm{pH}(7.1)$. Its low $\mathrm{C} / \mathrm{N}$ ratio (11.5) ensured easily mineralization (approximately 60\% for the first crop). The chicken manure contained very low amounts of heavy metals.

\subsection{Experimental design}

The experiment was conducted using a completely randomized design of six treatments and three repetitions. In April 2011, 18 plots of $1.5 \mathrm{~m}^{2}$ were established in a single-layer polythene greenhouse $\left(300 \mathrm{~m}^{2}\right)$ with automatic ventilation in Lugo (Galicia, NW Spain; $\left.42^{\circ} 59^{\prime} \mathrm{N} 7^{\circ} 32^{\prime} \mathrm{W}\right)$. The treatments included three compost rates $\left(40,50\right.$ and $66 \mathrm{tha}^{-1}$ (fresh weight), designated $\mathrm{C} 1, \mathrm{C} 2$ and C3, respectively); one slow-release NPK (20-2.2-8.3) treatment of mineral fertilizer $(\mathrm{M})$ applied at a rate of $1.15 \mathrm{t} \mathrm{ha}^{-1}$; and one commercial organic fertilizer based on dried broiler litter (BL) certified for organic agriculture ( $15 \mathrm{tha}^{-1}$ fresh weight). A control treatment (C), without fertilizers, was also included. The above-mentioned treatments were applied by superficial ploughing $(10 \mathrm{~cm})$.

Treatment compost rates were calculated based on the demand of $230 \mathrm{~kg} \mathrm{ha}^{-1} \mathrm{~N}$ for approximately $110 \mathrm{tha}^{-1}$ tomato yield (Rodriguez del Rincón, 1982) and considering an annual rate of mineralization of $60 \%$ for BL (Evers, 1998), and lower rates for the compost were used ( $50 \%$ for $\mathrm{C} 1,40 \%$ for $\mathrm{C} 2$, and $30 \%$ for $\mathrm{C} 3$ ) due to the higher $\mathrm{C} / \mathrm{N}$ ratio of the compost. A summary of all of the treatments can be seen in Table 1 .

\subsection{Tomato-lettuce rotation}

Six greenhouse-reared tomato seedlings (Solanum Lycopersicum var. Valentim (Seragrap)) were planted in each plot (108 plants in total), with a between-plant spacing of $0.50 \mathrm{~m}$. The plants were trained on vertical poles and the apical buds were removed after 
Table 1

Fertilization treatments: N-P-K content, rates applied, amounts of nutrients applied and availability for the first crop.

\begin{tabular}{|c|c|c|c|c|c|}
\hline & M & $\mathrm{BL}$ & $\mathrm{C} 1$ & $\mathrm{C} 2$ & $\mathrm{C} 3$ \\
\hline Composition N-P-K (\% DW ${ }^{\mathrm{a}}$ ) & $20-2.2-8.3$ & $3-1.3-2.5$ & $2-0.6-0.7$ & & \\
\hline Dose $\left(\mathrm{tha}^{-1} \mathrm{FW}^{\mathrm{b}}\right)$ & 1.15 & 15 & 40 & 50 & 66 \\
\hline Total $\mathrm{N}\left(\mathrm{kg} \mathrm{ha}^{-1}\right)$ & 230 & 387 & 464 & 580 & 765 \\
\hline Total $\mathrm{P}\left(\mathrm{kg} \mathrm{ha}^{-1}\right)$ & 33 & 170 & 143 & 179 & 236 \\
\hline Total $\mathrm{K}\left(\mathrm{kg} \mathrm{ha}^{-1}\right)$ & 125 & 321 & 187 & 241 & 317 \\
\hline $\mathrm{N}$ available ${ }^{\mathrm{c}}\left(\mathrm{kg} \mathrm{ha}^{-1}\right)$ & 230 & 232 & 232 & 232 & 230 \\
\hline P available ${ }^{\mathrm{c}}\left(\mathrm{kg} \mathrm{ha}^{-1}\right)$ & 33 & 102 & 72 & 71 & 71 \\
\hline $\mathrm{K}_{\text {available }}^{\mathrm{c}}\left(\mathrm{kg} \mathrm{ha}^{-1}\right)$ & 125 & 193 & 94 & 96 & 95 \\
\hline
\end{tabular}

production of the 6th raceme. When the first raceme stopped producing fruits, the lower leaves were removed to improve aeration of the plants. Lateral shoots were removed throughout tomato production. The crop was watered twice a day using a drip system with a variable dose to satisfy the crop requirements (170 $\mathrm{L} \mathrm{plant}^{-1}$ over the entire cycle). Phytosanitary treatments compatible with organic production (active substances: neem seed oil; copper phosphonate; dispersants and tensioactive substances) were applied to prevent and treat pests and diseases (mainly Trialeuroides vaporarium, Autographa gamma, Botrytis cinerea and Phytophthora infestans). Over 80 days, the tomatoes from the four central plants of the six plants in each plot were harvested at color stage 5 (60-90\% of the fruit is red) (Grierson and Kader, 1986). The recorded data included the number of fruits per plant, fresh weight and the diameter of the fruits. At three different stages of the study (initial, intermediate and final), a composite sample was harvested from each plot to determine the dry tomato weight.

After removing the tomato plants (May 2012), lettuces (Latuca sativa cv. Santoro) were planted in the same experimental plots without additional fertilization to evaluate the residual effects of the fertilizers. Twenty lettuce seedlings were planted in a herringbone configuration in each plot, with a plant spacing of $0.3 \mathrm{~m}$. The crop was watered twice a day with a drip system (16 L plant ${ }^{-1}$ over the entire cycle). After 40 days, the lettuces were harvested and weighed (fresh weight). Samples of 5 lettuces from each plot were used to determine the lettuce dry matter content. To evaluate the nitrate content of the internal and external leaves, three lettuces were collected from each plot following the recommendations of the European directive (EC Regulation 466/2001, 2001). The leaves were then pressed according to the method proposed by Alt and Füll (1987) to obtain an extract for determination of the nitrate content with a CRISON selective electrode (Consalteri et al., 1992).

\subsection{Chemical and physicochemical characterization of the soil}

At the end of the tomato crop (6 months after planting) and at the end of the lettuce crop ( 15 months after tomato planting), a soil sample of each plot was collected from the arable layer $(0-20 \mathrm{~cm})$.
The samples were air-dried, sieved $(<2 \mathrm{~mm})$ and stored for subsequent analysis.

The soil $\mathrm{pH}$ was determined following the method described by Guitián-Ojea and Carballas (1976) and the electrical conductivity of the saturated extract (Richards, 1941) was determined using a CRISON conductivimeter. The carbon and nitrogen contents were measured using a carbon-nitrogen element analyzer (CHNS LECO, TruSpec model). The exchanged cations were extracted with $1 \mathrm{~N}$ $\mathrm{NH}_{4} \mathrm{Cl}$ (Peech et al., 1947) and determined by atomic adsorption spectrophotometry ( $\mathrm{Ca}, \mathrm{Mg}$ and $\mathrm{Al}$ ) or flame emission spectrophotometry ( $\mathrm{Na}$ and $\mathrm{K}$ ) (Varian SPECTRAA $220 \mathrm{FS}$ ). The available phosphorus was extracted with $0.5 \mathrm{M} \mathrm{NaHCO}_{3}$ and the P content was determined by colorimetry (Olsen and Sommers, 1982).

\subsection{Statistical analysis}

Statistical analysis of the data was carried out with SPSS version 17.0. Treatment mean values were compared by ANOVA and significant differences $(p<0.05)$ between treatments were determined by Duncan's test. The relationships between the different crop characteristics were assessed by the Pearson's correlation coefficient at a significance level of $p<0.05$.

\section{Results and discussion}

\subsection{Tomato production}

Tomato yield was not significantly improved with mineral fertilization (Table 2) probably due to the initial high fertility of the greenhouse soil, to which fertilizers were added over several years. However, differences in the tomato yield were observed between treatments with the highest compost rate (C3) and with the control (Table 2). Although the production of the BL-fertilized crop was not significantly different from the $\mathrm{C}$ crop, it also showed higher production rates, with a similar harvest to the C3-fertilized crop. This shows the beneficial effects of both organic fertilizers, which in the case of the compost could go beyond the supply of nutrients because seaweed is known to have a beneficial effect on soil

Table 2

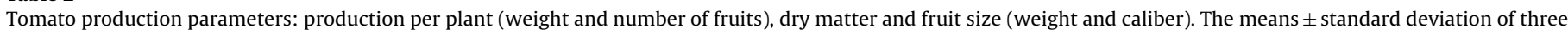
replicates are reported.

\begin{tabular}{|c|c|c|c|c|c|}
\hline & $\mathrm{kg}$ tomato per plant & DM\%a & No of fruits per plant & $\mathrm{g}$ fruit $^{-1}$ & Diameter (mm) \\
\hline Control & $4.54 \pm 0.69 \mathrm{~A}$ & $6.09 \pm 0.69 a b$ & $29.60 \pm 4.61 \mathrm{a}$ & $154.5 \pm 19.9 a$ & $70.28 \pm 3.51 a$ \\
\hline Mineral & $4.58 \pm 1.01 \mathrm{a}$ & $6.48 \pm 0.42 b$ & $30.50 \pm 4.40 a$ & $151.3 \pm 30.2 \mathrm{a}$ & $69.46 \pm 5.33 a$ \\
\hline $\mathrm{BL}$ & $4.88 \pm 1.08 \mathrm{ab}$ & $6.16 \pm 0.57 a b$ & $30.36 \pm 3.27 a$ & $161.0 \pm 32.9 a$ & $70.74 \pm 5.45 a$ \\
\hline $\mathrm{C} 1$ & $4.65 \pm 0.72 a$ & $6.03 \pm 0.83 a b$ & $31.71 \pm 4.73 a$ & $148.0 \pm 23.7 a$ & $69.23 \pm 4.70 \mathrm{a}$ \\
\hline $\mathrm{C} 2$ & $4.63 \pm 0.98 \mathrm{a}$ & $6.40 \pm 0.39 a b$ & $28.79 \pm 6.93 a$ & $162.9 \pm 19.4 a$ & $71.78 \pm 3.34 \mathrm{ab}$ \\
\hline $\mathrm{C} 3$ & $5.56 \pm 1.25 b$ & $5.69 \pm 0.61 a$ & $29.91 \pm 6.28 \mathrm{a}$ & $185.6 \pm 17.5 b$ & $74.79 \pm 3.07 b$ \\
\hline
\end{tabular}

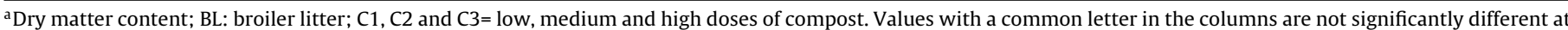
the 5\% level (Duncan's Multiple Range Test). 


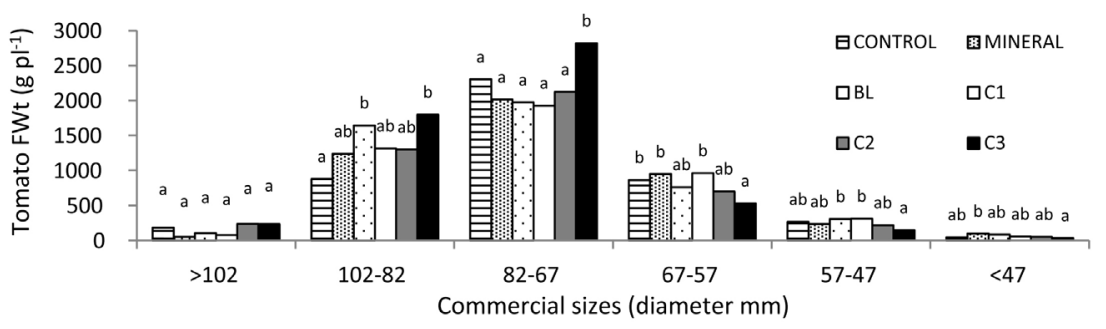

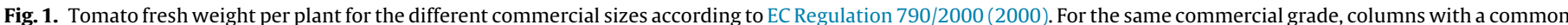
letter are not significantly different at the 5\% level (Duncan's Multiple Range Test).

physical conditions due to its high alginate content (Blunden, 1991; Verkleij, 1992; Eyras et al., 2008), and it is also known to stimulate plant growth due to its high contents of growth regulators, such as auxins and cytokinins (Stirk et al., 2004). The tomato yields increased with the treatment $\mathrm{C} 3$ compared to the $\mathrm{M}$ and $\mathrm{C}$ treatments, which was associated with increased fruit weight and larger fruit diameters but not with an increased number of fruits.

The tomato dry matter content (Table 2) was within the usual range reported for tomatoes (Davies et al., 1981). The application of mineral fertilizer significantly increased the tomato dry matter content (6.5\%) compared to treatment C3 (5.7\%), which was probably associated with the increased yield found for this last treatment. Some researchers have reported a negative relationship between the dry matter content and the size of the fruits (Ho, 1996), which is similar to the findings of this study in which this relationship $(R=-0.522)$ was significant $(p<0.05)$. A higher dry matter content indicates a higher level of soluble solids and therefore higher sugar content.

Regarding the marketable characteristics of the tomatoes, the largest commercially viable fruit size was found for tomatoes grown with the $\mathrm{C} 3$ treatment. However, in all treatments, most of the fruits were of caliber G (82-67 mm according to EC Regulation $790 / 2000,2000)$. From a management perspective, productive varieties that are also uniform in terms of fruit size are of interest (Nuez, 1995). Here, treatment C3 was associated with the most homogeneous size; $82.7 \%$ of the fruits were of caliber $108-82$ and $82-67 \mathrm{~mm}$, while only $74.2 \%$ in the BL crop and $70.0 \%$ in the C crop were into this range (Fig. 1).

The tomato fresh weights and accumulated yields are shown in Fig. 2. The weight of the tomatoes showed a steady decline throughout the crop cycle, although this decrease was less marked in plants

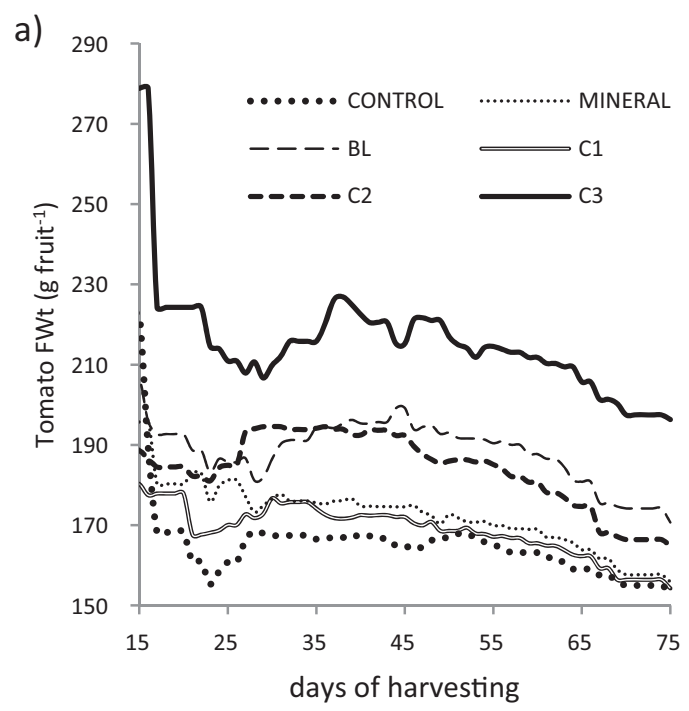

fertilized with the highest compost rate (Fig. 2a). This was reflected by higher yields mainly at the end of the crop cycle (Fig. 2b), which is beneficial for maintaining a stable level of production throughout the whole crop. However, in the trial conducted by Heeb et al. (2006), the yields of red tomatoes from plants organically fertilized were significantly lower $\left(1.3-1.8 \mathrm{~kg} \mathrm{plant}^{-1}\right)$ than the yields from plants that received mineral fertilizer $\left(2.2-2.8 \mathrm{~kg} \mathrm{plant}^{-1}\right)$. The authors attributed these differences to a low nutrient availability at the initial stages of the crop cycle. The sustained production in the plots treated with organic products in this study may indicate a good availability of nutrients from the start of the trial.

\section{Residual effects of the compost on the lettuce yield}

One of the main benefits of organic fertilizers is the release of available nutrients into soil, which may last for several years (Eghball, 2002). This residual effect may lead to increased production for up to four years after application of the organic fertilizer (Wallingford et al., 1975).

Crop yield differences between treatments were clearer for lettuce (Table 3 ) compared to the previous tomato crop. Tomato is a nutrient-demanding crop that rapidly depletes the available soil nutrients such that additional supplies are usually required for subsequent crops (Broadley et al., 2003). This is consistent with the fact that plots treated with the mineral fertilizer produced a similar harvest to the $C$ plots, which had not been fertilized. Except for the lowest compost rate ( $\mathrm{C} 1$ ), the organic fertilizers had a strong residual effect that significantly improved the yield of lettuce compared to the obtained with the mineral fertilizers or without fertilization. The highest lettuce yield was attained in the treatment with dehydrated broiler litter, which is consistent with the results reported by

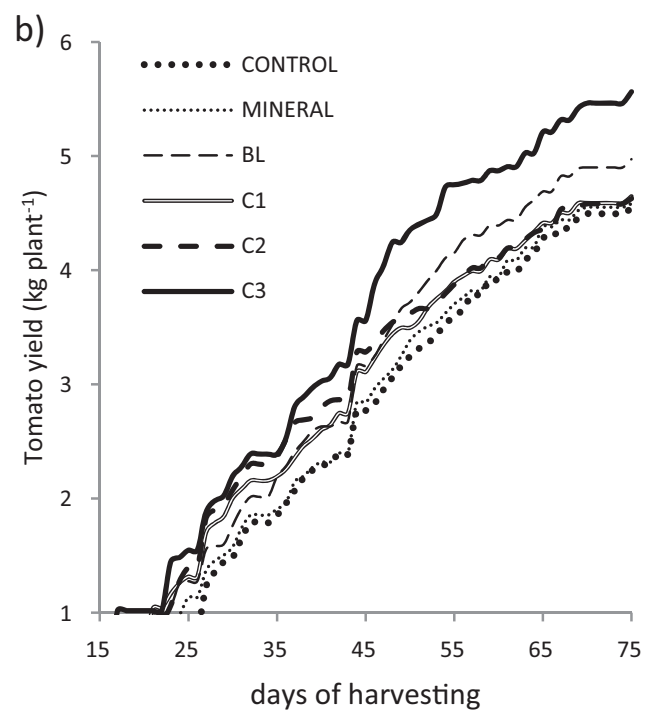

Fig. 2. The evolution of tomato production during harvest time. (a) Tomato fresh weight ( $\mathrm{g} \mathrm{fruit}^{-1}$ ); and (b) tomato yield (kg plant ${ }^{-1}$ ). 
Table 3

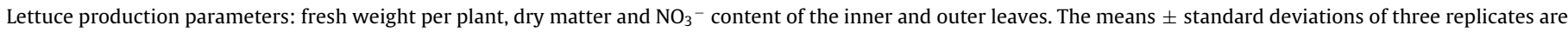
presented.

\begin{tabular}{|c|c|c|c|c|}
\hline & Fresh weight ( glettuce $^{-1}$ ) & Dry matter (\%) & $\mathrm{NO}_{3}{ }^{-}$inner leaves $\left(\mathrm{mg} \mathrm{NO}_{3}{ }^{-} \mathrm{kg}^{-1} \mathrm{FW}^{\mathrm{a}}\right)$ & $\mathrm{NO}_{3}{ }^{-}$outer leaves $\left(\mathrm{mg} \mathrm{NO}_{3}{ }^{-} \mathrm{kg}^{-1} \mathrm{FW}^{\mathrm{a}}\right)$ \\
\hline Control & $278.6 \pm 88.7 a$ & $5.87 \pm 0.69 c$ & $649.4 \pm 52.7 \mathrm{ab}$ & $1020.0 \pm 346.9 a$ \\
\hline Mineral & $230.5 \pm 85.3 a$ & $6.50 \pm 0.70 \mathrm{~d}$ & $636.3 \pm 159.3 \mathrm{ab}$ & $1523.8 \pm 346.0 \mathrm{~b}$ \\
\hline $\mathrm{BL}$ & $476.2 \pm 154.2 c$ & $4.80 \pm 0.89 \mathrm{ab}$ & $777.3 \pm 107.5 c$ & $1991.5 \pm 447.6 c$ \\
\hline $\mathrm{C} 1$ & $278.4 \pm 107.3 a$ & $5.35 \pm 1.06 b c$ & $589.2 \pm 85.7 a$ & $1219.2 \pm 398.6 a b$ \\
\hline $\mathrm{C} 2$ & $395.3 \pm 120.7 b$ & $4.41 \pm 0.47 a$ & $620.4 \pm 85.9 a b$ & $1221.4 \pm 453.1 \mathrm{ab}$ \\
\hline $\mathrm{C} 3$ & $367.0 \pm 160.9 b$ & $5.43 \pm 1.13 \mathrm{bc}$ & $742.9 \pm 176.1 \mathrm{bc}$ & $2080.2 \pm 256.2 c$ \\
\hline
\end{tabular}

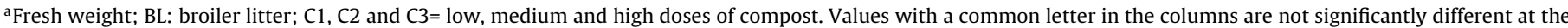
$5 \%$ level (Duncan's Multiple Range Test).

Table 4

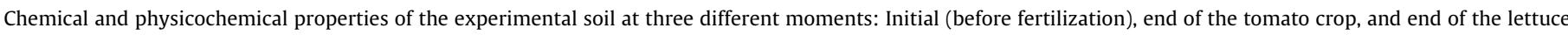
crop (0, 6 and 15 months after tomato planting, respectively). The means \pm standard deviations of three replicates are presented.

\begin{tabular}{|c|c|c|c|c|c|c|}
\hline Months after treatment & C & M & $\mathrm{BL}$ & $\mathrm{C} 1$ & $\mathrm{C} 2$ & $\mathrm{C} 3$ \\
\hline \multicolumn{7}{|l|}{$\mathrm{Ph}$} \\
\hline 0 & $4.2 \pm 0.2$ & & & & & \\
\hline 6 & $4.6 \pm 0.2 \mathrm{a}$ & $4.4 \pm 0.3 a$ & $4.5 \pm 0.0 \mathrm{a}$ & $4.6 \pm 0.1 \mathrm{a}$ & $4.7 \pm 0 \mathrm{~A}$ & $4.7 \pm 0.2 \mathrm{a}$ \\
\hline 15 & $5.0 \pm 0.4 a$ & $4.7 \pm 0.2 \mathrm{a}$ & $5.1 \pm 0.0 \mathrm{~b}$ & $4.8 \pm 0.1 \mathrm{a}$ & $4.9 \pm 0 \mathrm{ab}$ & $5.0 \pm 0.1 \mathrm{ab}$ \\
\hline \multicolumn{7}{|l|}{$\mathrm{EC}^{\mathrm{a}}\left(\mathrm{dS} \mathrm{m}^{-1}\right)$} \\
\hline 0 & $5.6 \pm 1.1$ & & & & & \\
\hline 6 & $3.8 \pm 1.5 \mathrm{a}$ & $3.7 \pm 0.3 a$ & $3.5 \pm 1 \mathrm{a}$ & $2.4 \pm 0.3 a$ & $2.5 \pm 0 \mathrm{~A}$ & $2.8 \pm 0.9 \mathrm{a}$ \\
\hline 15 & $1.8 \pm 1.2 \mathrm{a}$ & $2.6 \pm 1.8 \mathrm{a}$ & $1.7 \pm 1 \mathrm{a}$ & $1.7 \pm 0.8 \mathrm{a}$ & $1.5 \pm 1 \mathrm{~A}$ & $2.2 \pm 1.9 \mathrm{a}$ \\
\hline \multicolumn{7}{|l|}{$\mathrm{C}(\%)$} \\
\hline 0 & $1.8 \pm 0.3$ & & & & & \\
\hline 6 & $1.9 \pm 0.3 \mathrm{a}$ & $2.1 \pm 0.4 \mathrm{a}$ & $2.1 \pm 0.0 \mathrm{a}$ & $2.1 \pm 0.6 a$ & $2.2 \pm 0.0 \mathrm{~A}$ & $2.1 \pm 0.1 \mathrm{a}$ \\
\hline 15 & $2.3 \pm 0.4 a$ & $2.5 \pm 0.3 a$ & $3.0 \pm 0.0 \mathrm{a}$ & $2.5 \pm 0.4 a$ & $2.7 \pm 00 . \mathrm{A}$ & $2.7 \pm 0.3 a$ \\
\hline \multicolumn{7}{|l|}{$\mathrm{N}(\%)$} \\
\hline 0 & $0.25 \pm 0.04$ & & & & & \\
\hline 6 & $0.21 \pm 0.02 \mathrm{a}$ & $0.26 \pm 0.05 a$ & $0.25 \pm 0.02 \mathrm{a}$ & $0.24 \pm 0.05 a$ & $0.22 \pm 0.04 \mathrm{~A}$ & $0.22 \pm 0.04 a$ \\
\hline 15 & $0.18 \pm 0.05 a$ & $0.21 \pm 0.03 a$ & $0.19 \pm 0.01 a$ & $0.19 \pm 0.03 a$ & $0.21 \pm 0.03 \mathrm{~A}$ & $0.21 \pm 0.03 a$ \\
\hline \multicolumn{7}{|l|}{$\mathrm{C} / \mathrm{N}$} \\
\hline 0 & $7.3 \pm 0.6$ & & & & & \\
\hline 6 & $8.9 \pm 0.5 \mathrm{ab}$ & $8.2 \pm 0.7 a$ & $8.3 \pm 1 \mathrm{a}$ & $8.6 \pm 0.8 \mathrm{ab}$ & $10.2 \pm 0 \mathrm{~B}$ & $9.7 \pm 0.5 \mathrm{ab}$ \\
\hline 15 & $13.1 \pm 1.1 \mathrm{a}$ & $11.89 \pm 0.4 a$ & $11.87 \pm 1 \mathrm{a}$ & $13.5 \pm 1.1 \mathrm{a}$ & $12.9 \pm 1 \mathrm{~A}$ & $13.1 \pm 0.5 a$ \\
\hline \multicolumn{7}{|l|}{$\mathrm{CEC}_{\mathrm{e}}{ }^{\mathrm{b}}\left(\mathrm{cmol}(+) \mathrm{kg}^{-1}\right)$} \\
\hline 0 & $8.23 \pm 1.31$ & & & & & \\
\hline 6 & $7.11 \pm 1.42 \mathrm{a}$ & $7.74 \pm 1.10 \mathrm{a}$ & $7.20 \pm 0.75 a$ & $6.93 \pm 0.76 a$ & $6.52 \pm 0.04 \mathrm{~A}$ & $7.38 \pm 0.98 a$ \\
\hline 15 & $7.39 \pm 3.12 \mathrm{a}$ & $5.07 \pm 1.20 \mathrm{a}$ & $7.03 \pm 0.66 a$ & $6.10 \pm 0.38 a$ & $6.03 \pm 0.54 \mathrm{~A}$ & $6.95 \pm 1.10 \mathrm{a}$ \\
\hline \multicolumn{7}{|l|}{$\mathrm{K}\left(\mathrm{cmol}(+) \mathrm{kg}^{-1}\right)$} \\
\hline 0 & $0.60 \pm 0.20$ & & & & & \\
\hline 6 & $0.46 \pm 0.08 \mathrm{a}$ & $0.51 \pm 0.07 a$ & $0.92 \pm 0.0 \mathrm{~b}$ & $0.44 \pm 0.1 \mathrm{a}$ & $0.49 \pm 0.0 \mathrm{~A}$ & $0.49 \pm 0.04 a$ \\
\hline 15 & $0.42 \pm 0.17 a$ & $0.35 \pm 0.06 a$ & $0.58 \pm 0.0 \mathrm{~b}$ & $0.35 \pm 0.0 \mathrm{a}$ & $0.37 \pm 0.0 \mathrm{~A}$ & $0.37 \pm 0.03 a$ \\
\hline \multicolumn{7}{|l|}{$\mathrm{Ca}\left(\mathrm{cmol}(+) \mathrm{kg}^{-1}\right)$} \\
\hline 0 & $6.06 \pm 1.64$ & & & & & \\
\hline 6 & $5.14 \pm 1.08 a$ & $5.61 \pm 1.19 a$ & $4.60 \pm 0.52 a$ & $4.60 \pm 0.37 a$ & $4.28 \pm 0.03 \mathrm{~A}$ & $5.19 \pm 1.22 a$ \\
\hline 15 & $5.41 \pm 2.17 a$ & $3.50 \pm 0.85 a$ & $5.15 \pm 0.49 a$ & $4.25 \pm 0.40 a$ & $4.14 \pm 0.35 \mathrm{~A}$ & $4.99 \pm 1.05 a$ \\
\hline \multicolumn{7}{|l|}{$\operatorname{Mg}\left(\mathrm{cmol}(+) \mathrm{kg}^{-1}\right)$} \\
\hline 0 & $0.83 \pm 0.18$ & & & & & \\
\hline 6 & $0.73 \pm 0.19 a$ & $0.77 \pm 0.16 a$ & $0.74 \pm 0.00 \mathrm{a}$ & $0.62 \pm 0.10 a$ & $0.6 \pm 0.00 \mathrm{~A}$ & $0.68 \pm 0.04 a$ \\
\hline 15 & $0.76 \pm 0.43 a$ & $0.47 \pm 0.14 a$ & $0.82 \pm 0.00 a$ & $0.59 \pm 0.10 \mathrm{a}$ & $0.6 \pm 0.00 \mathrm{~A}$ & $0.71 \pm 0.16 a$ \\
\hline \multicolumn{7}{|l|}{$\mathrm{Na}\left(\mathrm{cmol}(+) \mathrm{kg}^{-1}\right)$} \\
\hline 0 & $0.44 \pm 0.09$ & & & & & \\
\hline 6 & $0.34 \pm 0.07 a$ & $0.36 \pm 0.09 a$ & $0.52 \pm 0.16 a$ & $0.66 \pm 0.35 a$ & $0.55 \pm 0.05 \mathrm{~A}$ & $0.65 \pm 0.07 a$ \\
\hline 15 & $0.52 \pm 0.35 a$ & $0.26 \pm 0.04 a$ & $0.41 \pm 0.08 a$ & $0.49 \pm 0.10 \mathrm{a}$ & $0.51 \pm 0.14 \mathrm{~A}$ & $0.56 \pm 0.13 a$ \\
\hline \multicolumn{7}{|l|}{$\mathrm{Al}\left(\mathrm{cmol}(+) \mathrm{kg}^{-1}\right)$} \\
\hline 0 & $0.39 \pm 0.09$ & & & & & \\
\hline 6 & $0.44 \pm 0.06 a$ & $0.48 \pm 0.27 a$ & $0.42 \pm 0.01 \mathrm{a}$ & $0.61 \pm 0.07$ & $0.59 \pm 0.14 \mathrm{~A}$ & $0.37 \pm 0.21 a$ \\
\hline 15 & $0.28 \pm 0.08 b$ & $0.49 \pm 0.13 b$ & $0.08 \pm 0.02 a$ & $0.42 \pm 0.10$ & $0.40 \pm 0.03 B$ & $0.32 \pm 0.18 b$ \\
\hline \multicolumn{7}{|l|}{$\mathrm{P}^{\mathrm{c}}\left(\mathrm{mg} \mathrm{kg}^{-1}\right)$} \\
\hline 0 & $30.4 \pm 3.4$ & & & & & \\
\hline 6 & $28.2 \pm 2.1 \mathrm{a}$ & $31.1 \pm 1.7 \mathrm{ab}$ & $43.2 \pm 4.5 c$ & $32.7 \pm 1.3 \mathrm{ab}$ & $34.9 \pm 1.1 \mathrm{~B}$ & $36.5 \pm 5.7 b$ \\
\hline 15 & $27.8 \pm 2.7 a$ & $34.1 \pm 8.0 \mathrm{ab}$ & $50.0 \pm 1.1 c$ & $34.1 \pm 2.1 \mathrm{ab}$ & $40.3 \pm 3.4 \mathrm{~B}$ & $38.8 \pm 0.9 b$ \\
\hline
\end{tabular}

a EC in saturation extract.

b Effective cation exchange capacity.

c P Olsen.

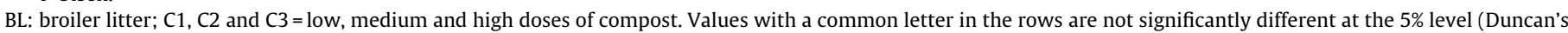
Multiple Range Test). 
Cabaleiro (2013). This author reported a significant residual effect of this same fertilizer on two commercial lettuce crops with a single initial dose of $5.3 \mathrm{tha}^{-1}$.

The lettuce yield was not improved with increased compost applications between C2 and C3. This may be explained by the increased tomato yield in $\mathrm{C} 3$, which led to increased nutrient uptake by the crop in this treatment and lower nutrient availability for the lettuce crop. The dry matter content of both lettuces and tomatoes tended to increase with the treatments associated with lower yields.

Leaf nitrate content is a quality factor for lettuce. EU Regulations (EC Regulation 466/2001, 2001) have established the maximum nitrate content for lettuce harvests collected between the 1st April and the 30th September at $3500 \mathrm{mg} \mathrm{NO}_{3}{ }^{-} \mathrm{kg}^{-1}$ (fresh weight), as higher contents may represent a risk for human health. Although the nitrate ion is not toxic, approximately $5 \%$ of the total nitrate ingested is transformed into nitrite, which is toxic (Spiegelhalder et al., 1976; Pannala et al., 2003). Therefore, it is crucial to find the optimal fertilizer rate that improves yields without decreasing the lettuce quality caused by the high nitrate content of the lettuce. In the present study, the lettuce nitrate content was always below the legal limits both in the outer and inner leaves (Table 3). The outer leaves, in which the greatest accumulation of nitrates generally occurs (Sánchez et al., 2002; Abu-Rayyan et al., 2004), showed the greatest differences between treatments. Nitrate accumulation increased for lettuces fertilized with BL or C3 compared to other treatments. This indicates that the availability of $\mathrm{N}$ was increased with the highest rate of compost application and broiler litter compared to the other treatments. The nitrate contents of the outer and inner leaves were positively and significantly correlated with the fertilizer rate $(p<0.05$ and $p<0.001$ for the inner and outer leaves, respectively).

\section{Fertilizer effects on soil characteristics}

The initial experimental soil $\mathrm{pH}$ value (4.2) was below the optimal level for tomato (5.5 to 6.8, according to Benton, 2007) and for lettuce (6.0 to 7.5, according to Nonnecke, 1989) (Table 4). The pH value increased during the growth of both crops in all treatments, but none reached optimal levels for these crops. In this trial, only the dehydrated broiler litter showed a significantly higher $\mathrm{pH}$ than the mineral plot at the end of the trial, which was a result of its liming amendment effect (Matos-Moreira et al., 2011). A complementary effect to that of $\mathrm{pH}$ was observed for the exchangeable $\mathrm{Al}$, which reached significantly lower levels in the BL-amended soil compared to the other treatments at 15 months after fertilizer application. These results are in accordance with the findings of Hue (1992) and Matos-Moreira et al. (2011), who used broiler litter fertilizer. Haynes and Mokolobate (2001) attributed this behavior not only to the increase in the $\mathrm{pH}$ but also to the high quality of organic matter in this fertilizer, which contains soluble humic compounds and aliphatic acids that allowed for Al complexation.

The electrical conductivity (EC) of the soil was initially high $\left(5.6 \mathrm{dS} \mathrm{m}^{-1}\right)$ and above the recommended maximum threshold $\left(2.5 \mathrm{dS} \mathrm{m}^{-1}\right)$ for tomato crops (Benton, 2007). However, the levels decreased during the experiment due to nutrient leaching by irrigation and nutrient uptake by the tomato crop. Thus, at the end of the tomato crop cycle, the EC was below the maximum threshold $\left(1.3 \mathrm{dS} \mathrm{m}^{-1}\right)$ indicated for lettuce crops by Maas and Hoffman (1977). Despite the marine origin of seaweed and fish waste, the compost application did not increase the soil EC, which is important from an agricultural point of view. There were no significant differences in the soil C content between treatments, indicating that the organic fertilizers was unable to increase these levels over such a short time, though it must be considered that the initial soil already had significant levels of $\mathrm{C}$. Nevertheless, soil C content (and therefore OM) generally increased with time, especially in the BL and C3 treatments (Table 4). The total soil $\mathrm{N}$ content generally showed a tendency to decrease during the experimental period, which may be due to the transformation of the organic $\mathrm{N}$ to inorganic forms that were absorbed by the crop, lost by lixiviation or released into the atmosphere as ammonia.

Although tomato is classified as a "heavy feeder" of $\mathrm{K}$ and $\mathrm{Ca}$ (Benton, 2007), no significant differences were found for these nutrient contents in tomato between treatments except when BL was applied, which increased soil P and K contents (Table 4). This is explained by the high $\mathrm{P}$ and $\mathrm{K}$ contents of this fertilizer (Table 1 ). With the application of BL, the exchangeable Al decreased significantly, reducing the precipitation of $\mathrm{Al}$ phosphates and thus improving P availability.

\section{Conclusions}

Compost from fish waste and seaweed was found to be a suitable soil amendment for horticultural crops grown using organic methods, as indicated by the tomato and lettuce yields.

The application of compost at a rate of $66 \mathrm{t} \mathrm{ha}^{-1}$ significantly increased the tomato yield and was associated with increased fruit weight and larger fruit diameter compared to crops receiving mineral fertilization or no fertilization.

The compost residual effect was significant and contributed to higher commercial yields for lettuce compared with the control and mineral fertilizer treatments. In spite of the high EC of the compost and the elevated rates used, the soil salinity did not increase. However, further investigation is required to show whether the yield increases can be attributed to the presence of other substances contained in the seaweed, such as growth regulators and alginates, which improve the physical, chemical and biological properties of soil.

\section{Acknowledge}

The authors acknowledge funding from Xunta de Galicia (Projects PGIDT05TAM097E and 09MRU016291PR, and a postgraduate grant for Marta Illera-Vives) and from Banco Santander (Mobility grant).

\section{References}

Abu-Rayyan, A., Kharawish, B.H., Al-Ismail, K., 2004. Nitrate content in lettuce (Lactuca sativa $\mathrm{L}$ ) heads in relation to plant spacing, nitrogen form and irrigation level. J. Sci. Food Agric. 84, 931-936.

Alt, D., Füll, A., 1987. Control of the nitrogen status of lettuce by nitrate analysis of plant sap. Acta Hortic. (ISHS) 222, 23-28.

Benton, J., 2007. Tomato Plant Culture: In the Field, Greenhouse, and Home Garden. CRC Press, Boca Raton, FL.

Blunden, G., 1991. Agricultural uses of seaweeds and seaweed extracts. In: Guiry, M.D., Blunden, G. (Eds.), Seaweed Resources in Europe: Uses and Potential. John Wiley and Sons Ltd, West Sussex, p. 81.

Broadley, M.R., Seginer, I., Burns, A., Escobar-Gutierrez, A.J., Burns, I.G., White, P.J. 2003. The nitrogen and nitrate economy of butterhead lettuce (Lactuca sativa var capitata L). J. Exp. Bot. 54, 2081-2090, DOI 1pa0.1093/jxb/erg222.

Cabaleiro, F.A., 2013. Valorización agronómica del estiércol deshidratado y granulado de pollo en cultivos hortícolas. Universidad de Santiago de Compostela (Thesis Dissertation). 〈http://hdl.handle.net/10347/9240〉.

Castro, R.S., Borges Azevedo, C., Bezerra-Neto, F, 2006. Increasing cherry tomato yield using fish effluent as irrigation water in Northeast Brazil. Sci. Hortic. 110 44-50.

Consalteri, A., Rigato, A., Clamor, L., Giandon, P., 1992. Determination of nitrate in vegetables using an ion-selective electrode. J. Food Compos. Anal. 5, 252-256.

Davies, J.N., Hobson, G.E., McGlasson, W., 1981. The constituents of tomato fruit-the influence of environment, nutrition, and genotype. Crit. Rev. Food Sci. 15 205-280.

EC Regulation 2092/91, 1991. Regulation 2092/91/EEC of 22 July 1991 on organic production of agricultural products and indications referring thereto on agricultural products and foodstuffs. Off. J. Eur. Communities L198 198, 15 
EC Regulation 466/2001, 2001. Commission Regulation (EC) No 466/2001 of 8 March 2001 Setting Maximum Levels for Certain Contaminants in Foodstuffs, vol. 77. DOL, pp. 1-13.

EC Regulation 790/2000, 2000. Commission Regulation (EC) No 790/200 of 14 April 2000 layingdown the marketing standard for tomatoes. DOUE (Diario Official de la Unión Europea) L95, 24-29.

Eghball, B., 2002. Soil properties as influenced by phosphorus-and nitrogen-based manure and compost applications. Agron. J. 94, 128-135.

EUROSTAT, 2013. Oficina Estadística De Las Comunidades Europeas. Eurostat, http://ec.europa.eu/eurostat.

Evers, G., 1998. Comparison of broiler poultry litter and commercial fertilizer for coastal bermudagrass production in the southeastern US. J. Sustainable Agric $12,55-77$.

Eyras, M.C., Defosse, G.E., Dellatorre, F., 2008. Seaweed compost as an amendment for horticultural soils in Patagonia, Argentina. Compos. Sci. Util. 16, 119-124.

Eyras, M.C., Rostagno, C.M., Defosse, G.E., 1998. Biological evaluation of seaweed composting. Compos. Sci. Util. 6, 74-81.

Frederick, L., Harris, R., Peterson, L., Kehrmeyer, S., 1989. Compost Solution to Dockside Fish Wastes. University of Wisconsin Sea Grant Advisory Services, Madison, WI, pp. 1-12.

Govindasamy, R., Zurbriggen, M., Italia, J., Adelaja, A., Nitzsche, P., Van Vranken, R., 1998. Farmers markets: consumer trends, preferences, and characteristics. J. Extension 52, 16.0

Grierson, D., Kader, A., 1986. Fruit ripening and quality. In: Atherton, J.G., Rudich, J. (Eds.), The Tomato Crop: A Scientific Basis for Improvement. Chapman and Hall, London, pp. 241-280.

Guitián-Ojea, F., Carballas, T., 1976. Técnicas de análisis de suelos. Pico Sacro, Santiago de Compostela, Spain.

Han, W., Clarke, W., Pratt, S., 2014. Composting of waste algae: a review. Waste Manage. 34, 1148-1155.

Haynes, R., Mokolobate, M., 2001. Amelioration of Al toxicity and P deficiency in acid soils by additions of organic residues: a critical review of the phenomenon and the mechanisms involved. Nutr. Cycling Agroecosyst. 59, 47-63.

Heeb, A., Lundegårdh, B., Savage, G., Ericsson, T., 2006. Impact of organic and inorganic fertilizers on yield, taste, and nutritional quality of tomatoes. J. Plant Nutr. Soil Sci. 169, 535-541.

Heeb, A., Lundegårdh, B., Ericsson, T., Savage, G.P., 2005a. Effects of nitrateammonium-, and organic-nitrogen-based fertilizers on growth and yield o tomatoes. J. Plant Nutr. Soil Sci. 168, 123-129.

Heeb, A., Lundegårdh, B., Ericsson, T., Savage, G.P., 2005b. Nitrogen form affects yield and taste of tomatoes. J. Sci. Food Agric. 85, 1405-1414

Ho, L.C., 1996. The mechanism of assimilate partitioning and carbohydrate compartmentation in fruit in relation to the quality and yield of tomato. J. Exp. Bot. 47, 1239-1243 (Spec No).

Hue, N., 1992. Correcting soil acidity of a highly weathered ultisol with chicken manure and sewage sludge. Commun. Soil Sci. Plant Anal. 23, 241-264.

Illera, M., Corral, R., Lema, E., Blanco, C., López-Mosquera, M.E., 2010. Caracterización de pescados para su uso como fertilizante en agricultura. En: Foro Rec. Mar. Ac. Rías Gal. (eds.) 13: 237-242. In: Rey-Méndez, M., Lodeiros, C., Fernández Casal, J., Guerra, A. (Eds.), Foro dos recursos mariños e da acuicultura das rías galegas. Asociación Foro dos Recursos Mariños e da Acuicultura das Rías Galegas, España pp. 237-242

Illera-Vives, M., Seoane Labandeira, S., López-Mosquera, M., 2013. Production of compost from marine waste: evaluation of the product for use in ecological agriculture. J. Appl. Phycol. 25, 1395-1403.

Kanal, A., Kuldkepp, P., 1993. Direct and residual effect of different organic fertilizers on potato and cereals. J. Agron. Crop. Sci. 171, 185-195.

Kong, A.Y., Six, J., Bryant, D.C., Denison, R.F., Van Kessel, C., 2005. The relationship between carbon input, aggregation, and soil organic carbon stabilization in sustainable cropping systems. Soil Sci. Soc. Am. J. 69, 1078-1085.

López-Mosquera, M.E., Pazos, P., 1997. Effects of seaweed on potato yields and soil chemistry. Biol. Agric. Hortic. 14 (3), 199-205.

Lopez-Mosquera, M., Cabaleiro, F., Sainz, M., López-Fabal, A., Carral, E., 2008. Fertilizing value of broiler litter: effects of drying and pelletizing. Bioresour. Technol. 99, 5626-5633

Maas, E., Hoffman, G., 1977. Crop salt tolerance $\backslash$-current assessment. J. Irrig. Drain. Div. ASCE 103, 115-134.

MAGRAMA, 2011. Anuario de Estadística 2010. Ministerio de Medio Ambiente, Medio Rural y Marino (MARM)

Matos-Moreira, M., Elvira López-Mosquera, M., Cunha, M., Jesús Sáinz Osés, M., Rodríguez, T., Carral, E.V., 2011. Effects of organic fertilizers on soil physicochemistry and on the yield and botanical composition of forage over 3 years. J. Air Waste Manage. Assoc. 61, 778-785.

McHugh, D.J., 2003. A Guide to the Seaweed Industry. Food and Agriculture Organization of the United Nations, Roma.

Michalak, I., Chojnacka, K., 2013. Algal compost-toward sustainable fertilization. Rev. Inorg. Chem. 33, 161-172.

Moral, R., Pedreño, J.N., Gomez, I., Palacios, G., Mataix, J., 1996. Tomato fruit yield and quality are affected by organic and inorganic fertilization and cadmium pollution. J. Plant Nutr. 19, 1493-1498.

Morand, P., Briand, X., 1996. Excessive growth of macroalgae: a symptom of environmental disturbance. Bot. Mar. 39, 491-516.

Niell, F., Fernández, C., Figueroa, F., Figueiras, F., Fuentes, J., Pérez-Llorens, J., GarciaSánchez, M., Hernández, I., Fernández, J., Espejo, M., 1996. Spanish Atlantic coasts. In: Schramm, W.N.P.H. (Ed.), Marine Benthic Vegetation. Recent Changes and the Effects of Eutrohication. Springer, Berlin, pp. 265-282.

Nonnecke, I.L., 1989. Vegetable Production. Springer, New York, NY

Nuez, F., 1995. El cultivo del tomate. Mundi-Prensa, Madrid.

Olsen, S., Sommers, L., 1982. Phosphorus. In: Page, A.L. (Ed.), Methods of Soil Analysis. Part 2. Agron, 9. American Society of Agronomy, Wisconsin, pp. 403-430.

Pannala, A.S., Mani, A.R., Spencer, J.P., Skinner, V., Bruckdorfer, K.R., Moore, K.P., RiceEvans, C.A., 2003. The effect of dietary nitrate on salivary, plasma, and urinary nitrate metabolism in humans. Free Radical Biol. Med. 34, 576-584.

Papenfus, H.B., Kulkarni, M.G., Stirk, W.A., Finnie, J.F., Van Staden, J., 2013. Effect of a commercial seaweed extract (Kelpak ${ }^{\circledR}$ ) and polyamines on nutrient-deprived (N, P and K) okra seedlings. Sci. Hortic-Amsterdam 151, 142-146.

Peech, M., Alexander, L.T., Dean, L.A., Reed, J.F., 1947. Methods of Soil Analysis for Soil-Fertility Investigations. USDA, Washington, DC.

Piriou, J., Menesguen, A., 1992. Environmental factors controlling the Ulva sp. blooms in Brittany (France). In: Colombo, G., Ferrari, I., Ceccherelli, V.U., Rossi, R. (Eds.), Marine eutrophication and population dynamics. Proceedings of the 25th European Marine Biology Symposium. Olsen \& Olsen, Fredendsbog, pp. 111-116.

Piriz, M.L., Eyras, M.C., Rostagno, C.M., 2003. Changes in biomass and botanical composition of beach-cast seaweeds in a disturbed coastal area from Argentine Patagonia. J. Appl. Phycol. 15, 67-74.

Potoky, P., Mazé, J., Morand, P., Schulte, E., 1998. Effect of seaweed inclusion in compost preparation on the quality of the composts obtained. In: Aquatic Primary Biomass (marine Macroalgae): Biomass Conversion, Removal and use of Nutrientes. Proceedings of the First Workshop of the Cost 48 sub Grroup 3, L'Homeau France, pp. 67-86

Reeves, D., 1997. The role of soil organic matter in maintaining soil quality in continuous cropping systems. Soil Tillage Res. 43, 131-167.

Richards, L., 1941. A pressure-membrane extraction apparatus for soil solution. Soil Sci. 51, 377-386.

Rodriguez del Rincón, A., 1982. Ensayo de tomate para industria en las Vegas de Guadiana [Badajoz, Espana]. ITEA 46, 17-29.

Rosenberg, R., 1985. Eutrophication-the future marine coastal nuisance? Mar. Pollut. Bull. 16, 227-231.

Sánchez, L.R., Crespo, A.P., Botía, C.P., Sironi, J.S., Sánchez, A.A., 2002. Influencia de la fertilización nitrogenada en la absorción de nitrógeno y acumulación de nitratos en la lechuga iceberg. Invest. Agric. Prod. Prot. Veg. 17, 2.

Spiegelhalder, B., Eisenbrand, G., Preussmann, R., 1976. Influence of dietary nitrate on nitrite content of human saliva: possible relevance to in vivo formation of N-nitroso compounds. Food Cosmet. Toxicol. 14, 545-548.

Stirk, W., Arthur, G., Lourens, A., Novak, O., Strnad, M., Van Staden, J., 2004. Changes in cytokinin and auxin concentrations in seaweed concentrates when stored at an elevated temperature. J. Appl. Phycol. 16, 31-39.

Verkleij, F.N., 1992. Seaweed extracts in agriculture and horticulture: a review. Biol. Agric. Hortic. 8, 309-324.

Wallingford, G., Murphy, L., Powers, W., Manges, H., 1975. Disposal of beef-feedlot manure: effects of residual and yearly applications on corn and soil chemical properties. J. Environ. Qual. 4, 526-531.

Weil, R.R., Magdoff, F., 2004. Significance of soil organic matter to soil quality and health. In: Soil Organic Matter in Sustainable Agriculture. CRC Press, Boca Raton, FL, pp. 1-43.

Willer, H., Kilcher, L., 2013. The World of Organic Agriculture: Statistics and Emerging Trends 2013: Frick, Switzerland: Research Institute of Organic Agriculture (FiBL) \& Bonn. International Federation of Organic Agriculture Movements (IFOAM), Rheinbreitbanch, Germany.

Zemke-White, W.L., Ohno, M., 1999. World seaweed utilisation: an end-of-century summary. J. Appl. Phycol. 11, 369-376. 